\title{
Metacultural (ethnolinguistic) competence and translation: classroom experience
}

\author{
N. M. Hrytsiv \\ Lviv Polytechnic National University, Lviv, Ukraine \\ Corresponding author. E-mail: nataliia.m.hrytsiv.lpnu.ua; nhrytsiv@yaho.com
}

Paper received 21.09.20; Accepted for publication 12.10.20.

\begin{abstract}
https://doi.org/10.31174/SEND-Ph2020-240VIII71-02
\end{abstract}
\begin{abstract}
The purpose of the article is to outline the place of metacultural (ethnolinguistic) competence in teaching translation, to trace and identify features of coexistence of related research priorities (culturological, anthropological, ethnolinguistic) on one educational ground and to characterize achievements of ethnolinguistics as a multidisciplinary discipline as applied in translator training classroom activity. From didactics perspective, prioritized was the necessity to investigate whether students perceived the language as an important element of the culture of a given community (here, English and Ukrainian). Findings have proven that ethnolinguistic competence helps students to identify lexical connotations established in the transitive sense of a word; recognize ethno specific elements of a given language; and suggest a well-considered translator's choice.
\end{abstract}

Keywords: translation, translator training, ethnolinguistic competence, cultural linguistics, anthropological linguistic.

Introduction. Recent decade has witnessed the shift to competence-based approach in philologist training; and, thus, opened new vistas for scholars in the issue of framing metacultural (ethnolinguistic) competence within the scope of interethnic communication and translation.

To some extent, the issue discussed becomes topical from the viewpoint of modern technological abilities. Though helpful, readymade translation suggestions - with the use of automated translation systems - deprive the learner of basic necessity to developing ethnic and cultural competences for bilingual learners and translator training along with other competences, such as linguistic and textual, research, technical, information, thematic, and translation competences.

Thus, the key purpose of the article is to outline the place of metacultural (ethno-linguistic) competence in teaching translation, to trace and identify the peculiarities of coexistence of related research priorities (cultural, anthropological, ethno-linguistic) on one learning ground and to characterize ethno-linguistic competence in translator training.

The competences to be advanced began with comparing students' knowledge and skills in the adjacent philological areas of Contrastive Linguistics, Applied Linguistics, Lexicology and Lexicography, Stylistics, Area and Culture Studies, Pragmatics. The assessment of student performance in selected discipline took place with the understanding, though, that students' success in study depends on a much wider range of competencies. Thus, prioritized competences provide a framework that can guide the longer-term extension of assessments into new competency domains.

Consequently, students are facilitated to develop their understanding of the given subject matter; they master their metalanguage, and eventually apply its rudiments into their scholarly discourse. Prioritized is the necessity to teach the student to see language as an important element of the culture of a given community and, thus, to clearly understand that a language does not only consist of grammatical rules that govern the words but, primarily, it is the way of receiving and describing the reality. The student is taught to accept diverse cultures and to be able to identify the ethnocentric attitude in the intercultural communication and, before everything else, to analyze its impact on the ethnotext translations.

Therefore, the aim of the paper is to review and classify counterparts of ethnolinguistic competence which is gained and mastered within Ethnolinguistics as a discipline with the perspective to be applied to translation, translation studies analysis, and translator training.

From translator training perspective, prioritized in the article is the necessity to stress the importance of cultural and ethnic differences not only from the viewpoint of recognizing, admitting culture specific units, consequently finding proper mechanisms of its rendition in target language, but, which is most important, to stress the urgent need to track the cultural inventory words to its roots, its origin and reasoning behind its cognition and categorization in such a specific way. This issue - formally called metacultural (ethnolinguistic) competence, gains considerable currency both within scholars and translator-students. The evidence to this is captured in, and later reconstructed from, the inquiry - Ethnolinguistic Competence in Translation Studies - designed for the second year students of Applied Linguistics department.

Methods. Research methods combine the insights of sociolinguistics with social and cultural anthropology. Sociolinguistics shares the assumption of a heterogeneous speech community and an analysis of the forms of speech within it. Sociocultural anthropology assumes cultural relativity and attempts to apply an emic view of the situation, that is, the one offered from the heart of ethnic group, along with an etic, external description of contextual reality. Anthropology involves an ethnographic method of continuous interpretation, interrelated with the ways of expressing ideas and placing them in contexts from which they derive meaning and to which they give meaning.

Instruments and Procedure include questionnaires and students feedbacks. Data Analysis driven from questionnaire results obtained via Google form, Excel possibilities. The participants were questioned anonymously, however having given their prior concern for participating in the study.

The study was conducted within three stages: preparatory, during which the hypotheses were formulated and the design of the experiment was developed, the main one was the practical implementation of the experiment and 
the final one, which included analysis and interpretation of the experimental data. We were most interested in the way students deal with the unfamiliar cultural inventory (vocabulary) and whether their translation suggestions are understood and perceived by the English native speakers.

Theories behind metacultural (ethnolinguistic) competence. Facilitating metaculrural (ethnolinguistic) competence of the students (learners) takes a complex of challenging questions facing anthropological linguists, cultural linguistics, ethnolinguistics, the unity of which studies the relationship between language, culture, and thought $[4 ; 7 ; 16]$. Theoretical elaborations concerning this topic have ranged from an idea that language shapes human thought and worldview to one that considers the three (language, culture and thought) to be separate systems $[2 ; 5 ; 8]$.

Modern Translation Studies share with anthropological linguists, cultural linguistics, ethnolinguistics, and cognitive linguistics the idea that meaning is conceptualized [6; $9 ; 10 ; 15 ; 17 ; 19]$. Apart from its achievements in the sphere of equivalency, Translation Studies rarely address the question in what way is the meaning conceptualisation in the source language and why is it differently conceptualized in the target language. The experiment showed that this why counterpart became of most interest amongst students of philological profile.

Therefore, the classroom practice behind this process should not be limited to simply declaring the divergences in world categorization and conceptualization within different nations (cultures, ethnic group), which are vividly captured in collocations and phraseology; the classroom training should acquire and develop the learners' ability to provide new insights into the complex relationships holding between languages, cultures and thought, especially in intercultural and interethnic settings.

In brief, Ethnolinguistic competence helps students to give answers to: directions?

Why some people do not differentiate cardinal

How can time be seen and comprehended vertically and horizontally? Mädchen)?

Why a German lady is of neutral gender (das

Why the same rainbow is seen in three to eight colors by different ethnic groups?

Why order of adjectives in English is so tremendously important?

How to explain difference in verbalizing the same linguistic phenomenon (peel your eyes vs poззуü очi).

First and foremost, because the perception of certain linguistic phenomena is culturally conditioned which means that in different cultures the same ideas may be experienced, perceived, conceptualized and categorized in diverse ways, that is why different ethnic groups express and verbalize the same world reality differently. This is the greatest challenge for translators from one language into other languages.

Within classroom activities, it should be specified that the perception of certain linguistic phenomena is culturally conditioned which means that in different cultures the same ideas may be experienced, perceived, conceptualized and categorized in diverse ways $[1 ; 6]$. The examples that students appreciate are of popular everyday lexemes.

Drawing on Cultural Linguistics, Sharifian [13] offers the notion of metacultural competence as a target for learners, in order to succeed in the use of English as a language of international communication. This competence enables interlocutors to communicate and negotiate their cultural conceptualisations during the process of intercultural or interethnic communication.

Taking into account that the prefix ethno involves a combining form meaning of "race," "people," or "culture," used in the formation of compound words, it becomes obvious that the notion of metacultural competence by Sharifian $[13 ; 14]$ echoes with ethnolinguistic competence as seen by the East scholars. To add, this is the same phenomena but seen, analysed and approached from different traditions (Eastern and Western).

We share the scholarly idea of Plas [12] who compared Slavic ethnolinguistics with its Anglo-American counterpart and with linguistic anthropology and stresses a parallelism between them: both find it necessary to underscore the inalienable link between language, culture, and cultural identity, as well as the importance of folk ethnographic accounts.

It should be mentioned that in the East, Ethnolinguistics is often referred to as Linguo-culturology or Cultural Linguistics. At the same time, in the West the term linguistic anthropology seems to prevail over anthropological linguistics. Thus, Ethnolinguistics is embedded within anthropological studies and Ethnolinguistics is here considered as a subdicipline of Anthropology [18].

In other words, Cultural Linguistics focuses the relationship between language and cultural conceptualisations, while Anthropology focuses on the speakers' mindset of a specific language.

Above all, it is apparent that nowadays there exists a diverse range of approaches (anthropological, social, cultural, ethnic) to cope with the task. In the majority of cases Ethnolinguistics is credited with folklore literary creativity, ethnorealia and challenges of their translation, and phraseology - therefore, rarely incorporated in the classroom, - which is, to our strong believe, unjustified. The matter is, that there exist two Ethnolinguistic traditions: Eastern (with focus on folklore) and Western (focusing on aspects Cultural Linguistics).

There are three components (schema, category, metaphor) that form metacultural (ethnolinguistic) competence.

Cultural schemas are a culturally constructed sub-class of schemas; that is, they are abstracted from the collective cognitions associated with a cultural group, and therefore to some extent based on shared experiences, common to the group, as opposed to being abstracted from an individual's idiosyncratic experiences.

Cultural schemas may also provide a basis for pragmatic meanings, in the sense that, knowledge which underlies the enactment and uptake of speech acts and that is assumed to be culturally shared is largely captured in cultural schemas.

The elaboration of schemas may help students to understand why does an English bride get 12 roses while Ukrainian gets an odd numbers of flowers. Or why do Slavonic nations wear the wedding ring on their right hand while the majority of the world uses their left hand 
for the same purpose.

Another class of cultural conceptualisation is that of the cultural category. Categorisation is one of the most fundamental human cognitive activities. It begins, albeit in an idiosyncratic way, early in life. Cultural categories exist for objects, events, settings, mental states, properties, relations and other components of experience (e.g. birds, weddings, parks, serenity, blue and above).

Cultural metaphors, according to Sharifian [13], is synonymous to conceptual metaphors and focuses on culturally constructed

In this respect, ethnomedical aspect would help the translator to learn that broken-heart in English and розбume cepue in Ukrainian mean the same unrequited love problems, while in in Indonesian it is 'the liver' that is associated with love, rather than the heart. It to, hypothetically, imagine the necessity to translate from Indonesian into Ukrainian or English, the phrase "damaged liver" would obtain a totally different meaning.

Therefore, as seen from above, in this paper we do not separate the terms metacultural and ethnolinguistic competence but consider both jointly.

Experiments and Results. An experimental study was conducted during spring 2020 (the second semester of the second year of bachelor studies), because it is this semester that students are taught the basics of ethnolinguistics and translation. Within this course students are introduced with a range of issues concerning interrelations between language, culture, and ethnicity, such as, between the formal language structure users and the rest of community that uses a given language. They are also familiarized with modern approaches to studying Ethnolinguistics as a marginal field of linguistics which borders with ethnology, culture studies, psycholinguistics directed to comprehending the reflection of speech patterns as well as spiritual cultural code, both encoded in language. Special attention is given to the practical application of Ethnolinguistics achievements to translation and Translation Studies. After course completion the students are expected to understand and differentiate principal approaches to studying Ethnolinguistics and Translation Studies as scholarly fields, they are supposed to know and make use of basic skills while working with bilingual ethnotexts. In this regard, many language samples are presented with the stress on English and Ukrainian to illustrate theoretical issues.

Stage 1. Profiling the knowledge and skills of the targeted focus group (second year students)

Instruments and Procedure include questionnaires and students feedbacks. The study was conducted within three stages: preparatory, during which the hypotheses were formulated and the design of the experiment was developed, the main one was the practical implementation of the experiment and the final one, which included analysis and interpretation of the experimental data. Dealing with the unfamiliar cultural inventory (vocabulary) students think in accordance with the categories of their native language and apply the logic of their mother culture and ethnic surrounding.

Hypothesis 1. Productive procedure to facilitate translator students feel the necessity to analyze the utterance beyond its semantic layer is to illustrate untranslatability (linguistic and cultural).
Hypothesis 2. Performing the in-class trial translation of an ethnotext within the area of metacultural (ethnolinguistic) competence convincingly demonstrates the improvement of the quality of students' translations.

To test the hypotheses, we selected 125 second year students of the Bachelor's Degree Program of the Department of Applied Linguistics at Lviv Polytechnic National University.

The questionnaire was designed to check two hypotheses with close attention to metacultural (ethnolinguistic) competence components (schema, category, metaphor).

Data analysis is driven from questionnaire results obtained via Google form, Excel possibilities.

The participants were questioned anonymously, however having given their prior concern for participating in the study.

Justification of Hypothesis 1. Productive procedure to facilitate translator students feel the necessity to analyze the utterance beyond its semantic layer is to illustrate untranslatability (linguistic and cultural).

At the beginning of the course Ethnolinguistics and Translation students were offered the questionnaire with a number of questions, some of the responses are presented below.

Firstly, we check general background knowledge of the students asking them a couple of idiomatic expressions or words with deeper semantic layer. For example, students are asked whether they know the expression "a fairweather friend" or how they understand the English phrase "to be on the fence".

Results of the answer to the question 'Do you know the expression "a fair-weather friend'?

Thus, general background knowledge of the students depicts that $58,4 \%$ know the answer. Despite the fact the phrase counterparts (fair, weather, friend) are easy to understand, $41,6 \%$ of students have never heard or do not know the meaning of the phrase discussed. Such an almost fifty-fifty is favorable. In case no one knew the answer we would have to consider easier (or of more frequent usage) phrases. The circumstances where up to $90 \%$ knew the phrase would demand high language proficiency, and, as a result, reconsidering the overall necessity of teaching basics of ethnolinguistics to second year students.

Table 1. Results on "How do you understand the English phrase 'to be on the fence'?"

\begin{tabular}{|l|l|}
\hline How do you understand the English phrase 'to be on the fence'? \\
\hline Assumption & Number of students \\
\hline To hesitate or to be unsure & 56 \\
\hline $\begin{array}{l}\text { Be successful (as derived from Ukrainian } \\
\text { бути на коні) }\end{array}$ & 11 \\
\hline To be stressed or afraid & 9 \\
\hline $\begin{array}{l}\text { Other (spy on smb, escape from the prob- } \\
\text { lems, be punished or guilty, avoid the dis- } \\
\text { pute) }\end{array}$ & 49 \\
\hline
\end{tabular}

The results show that the approximate percentage is fifty-fifty.

Next, students are shifted to translation-oriented activity. The table below shows that 53 students failed to know the correct translation. They, however, rotate their interpretation around the literal meaning of the lexeme. At this point they are taught and guided to see beyond first se- 
mantic layer and are driven to cultural category as a counterpart of metacultural (ethnolinguistic) competence. It is stressed that different people perceive and categorize the world, and, thus, linguistic picture, differently.

Table 2. Results on "Do you know how to translate into Ukrainian 'dog eared' in the relation to a book?"

Do you know how to translate into Ukrainian 'dog eared' in the relation to a book?

\begin{tabular}{|l|l|}
\hline Answers & Number of students \\
\hline No & 25 \\
\hline No, but I would like to learn it & 11 \\
\hline $\begin{array}{l}\text { Yes, it is закладка, загнутий кут книж- } \\
\text { ки, китиця, загнуті краӥ сторінок }\end{array}$ & 36 \\
\hline $\begin{array}{l}\text { First association answers: } \\
\text { Cобачі вуха } \\
\text { I think it is віслячi вуха or just вуха } \\
\text { Гострий слух } \\
\text { Мати гострий слух } \\
\text { Собачий слух } \\
\text { I сап guеss it is translated «гострий слух» } \\
\text { Слух як в собаки }\end{array}$ \\
\hline
\end{tabular}

In such a way a student is taught to identify diverse cultures schemas, categories, metaphors and to be able to incorporate this practice while translating.

This experiment illustrated that, eventually, students agreed on the importance to see language as an important element of the cultural conceptualization of a given community and, thus, to clearly understand that translation practice does not only presuppose rendering lexical and grammatical rules that govern the words but, first and foremost, it is the way of describing and reproducing the reality in accordance with their encoded meaning. This was further proven by their answers after Ethnolinguistics course completion.

Stage 2. Ethnolinguistic competence and practice of translation: case study.

Justification of Hypothesis 2. Performing the translation of an ethnotext within the area of metacultural (ethnolinguistic) competence convincingly demonstrates students' creative and intellectual vigour in terms of presenting good quality translations.

Taking into consideration that the participants are just the second year students, we have chosen Ukrainian ethnotext for translation, which, we believe, will be easier for the students on the level of schema, category and metaphor recognition. For the practical implementation of ethnolinguistic (metacultural) competence we have chosen Lina Kostenko's poetic lines “Бабуся-Ягуся”. Let us specify that the piece was chosen not otherwise than from the viewpoint of didactics and with the intention of schooling students and training translators. The volume of the text is 8 poetic lines, 45 words, 219 printed characters (without spaces).

Ліна Костенко. Бабуся Ягуся

Сьогодні ця паличка буде чарівна.

Це жаба не проста, це жаба-царівна.

Он котик воркотик, он Баба-Яга

між добрих людей на мітлі сновига.

Одне ж бо дівчатко, як біле гуся, сказало їй раптом: Бабуся-Ягуся!
А баба як тупне на нього ногою!..

Ото щоб Ягу називало Ягою [11].

Despite the fact each word is used once, the majority of them encodes culture and ethno specific schema, category, and metaphor. The ethnotext to be processed by students is a rhyme for children. Significant challenge for translation is hidden in ethnolinguistic conceptualization. Thus, in the rhyme we come across cultural untranslatability captured in a lullaby image of the kitten, Ukrainian analogue to an evil witch. Because of diminutive suffixation, certain lexemes are untranslatable from grammatical viewpoint. It should be mentioned that overall aim of Table 3 is to show the ethnotext features awareness of students rather then check their final translation choices.

Nevertheless, students' variants were accessed by marking their choices: Source Text oriented approach, thus preserving semantics to the best of its abilities; Target Text orientation.

The results of Table 6 provide us with the evidence that students recognize cultural inventory. The findings signify the fact that they have opted for modulating semantic structures of the ST in their desire to satisfy the pragmatic orientation in the TT. The students who preferred ST orientation have been looking for certain procedures of contextual explanation, compensation and paraphrases.

The experiment eventually resulted in a number of successful translations of didactic character which we share in this article upon the agreement of the authors of corresponding reproductions.

In order to collect English native speakers' feedbacks on students' experimental variations on the given Ukrainian ethnotext we have created Google form questionnaire. Presented in Table 4 are the results of the overall impression about the target text.

Implications of the Findings. The purpose of this study was to highlighten the merits of metacultural (ethnolinguistic) competence in translation training. Among the implications of the results obtained there are;

(a) encorporating metacultural (ethnolinguistic) competence for students of translation studies can teach the learners how to analyze ST and TT in order to evaluate the challenges of the original text both from Ukrainian into English or from English into Ukrainian, for that matter. In fact, knowing the theory within Ethnolinguistics and Translation Studies is as important as practice and the students can understand different concepts of different theories when they learn how to apply divergent ethnolinguistic concepts practically.

(b) the findings of this study are hoped to be of help to trainers of translating and those who are interested in the field of metacultural (ethnolinguistic) competence. In addition, comparing the source text with its translation by this model can give an insight in teaching translation because it offers the characteristics of the ST and TT languages. Therefore

(c) the results of this study can be used by the trainors (teachers) of translation in order to revise their approaches to teaching translation competences specially in the field of literary texts. 
Table 3. Ethnolinguistic inventory causing challenge for a translator

\begin{tabular}{|c|c|c|c|c|c|c|}
\hline \multicolumn{7}{|c|}{ Ethnolinguistic inventory causing challenge for a translator } \\
\hline Source text & 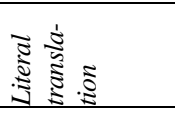 & Ethno meaning implied & 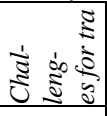 & Students variants & \multicolumn{2}{|c|}{$\begin{array}{l}\text { Translation } \\
\text { variants }\end{array}$} \\
\hline \multirow{4}{*}{ 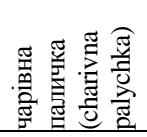 } & \multirow{4}{*}{ 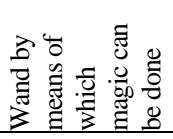 } & & \multirow{4}{*}{ 当芯 } & a magical wand & & + \\
\hline & & & & magic stick & & + \\
\hline & & & & magical cane & & + \\
\hline & & & & wand will be enchanting & & + \\
\hline \multirow{11}{*}{ 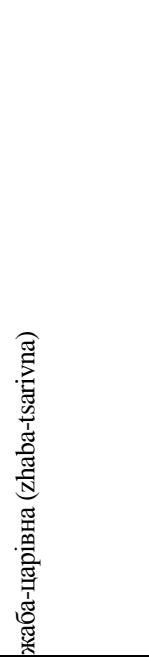 } & \multirow{11}{*}{ 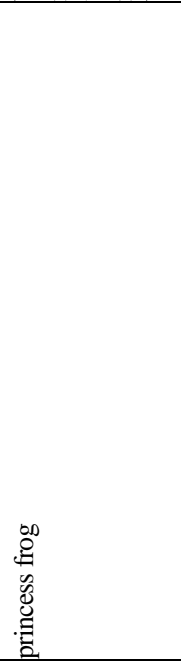 } & & \multirow{11}{*}{ 芯 } & princess frog & + & \\
\hline & & & & the frog princess (princess frog) & + & \\
\hline & & & & the frog is not untypical & & + \\
\hline & & & & it's the Frog Princess, not just usual & + & \\
\hline & & & & this frog is a princess, not a simpleton & + & \\
\hline & & & & not just a frog, but a Princess (Tsarivna) & + & \\
\hline & & & & the frog here isn't simple - it's a fantastical animal & & + \\
\hline & & & & frog is not normal, it‘s Quine, so you sway & & + \\
\hline & & & & a frog is Princess-toad & & + \\
\hline & & & & not simple frog, it's a royal one & & + \\
\hline & & & & not a common frog & & + \\
\hline \multirow{8}{*}{ 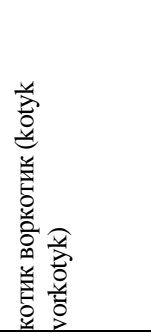 } & \multirow{8}{*}{$\begin{array}{l}\text { 竞 } \\
\text { 苞 }\end{array}$} & \multirow{8}{*}{$\begin{array}{l}\text { A lullaby image of the } \\
\text { kitten making sounds } \\
\text { for self-soothing pur- } \\
\text { poses, or to provide } \\
\text { comfort for other cats or } \\
\text { humans. }\end{array}$} & \multirow{8}{*}{ 芯 } & a purring kitten & + & + \\
\hline & & & & a purring cat & & + \\
\hline & & & & a kitten that purrs & + & + \\
\hline & & & & a kitty cat & & + \\
\hline & & & & here's kitty-too-sweetie & & + \\
\hline & & & & a furry cat & & + \\
\hline & & & & a pussycat & & + \\
\hline & & & & a kitty cat purrs & + & \\
\hline \multirow{8}{*}{ 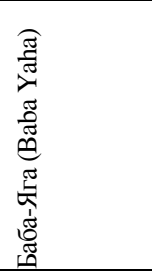 } & \multirow{8}{*}{ 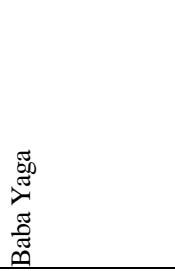 } & & & Baba-Yaga & + & \\
\hline & & shrew, a witch or & & a woman whose name is terrible and scary & & + \\
\hline & & harridan who scares & & grandma Yaga & + & \\
\hline & & Ukrainian children. & & Harridan & & + \\
\hline & & Widely depicted in & & Baba Yaga-witch & + & + \\
\hline & & & 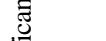 & a grandma-hag & + & + \\
\hline & & & 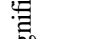 & Baba Yaha & + & \\
\hline & & & $\frac{50}{60}$ & Witch & & + \\
\hline & $\widetilde{6}$ & Diminutive from of & & Granny-hag & + & + \\
\hline 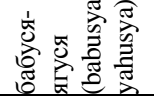 & 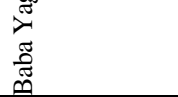 & $\begin{array}{l}\text { Baba Yaha. It is un- } \\
\text { translatable from } \\
\text { grammatical viewpoint. }\end{array}$ & & Granny & & + \\
\hline & & Fixed in the Ukrainian & & a Baba-Yaga, loitering on the broom & + & \\
\hline כ్ & $\Xi$ & mentality, broomstick is & & a Baba-Yaga on the broom flying & + & \\
\hline 葛 & 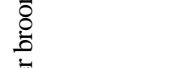 & $\begin{array}{l}\text { a travelling vehicle of } \\
\text { Baba Yaha }\end{array}$ & & $\begin{array}{l}\text { a woman. She flies her broom all around the world } \\
\text { being so inhuman }\end{array}$ & & + \\
\hline 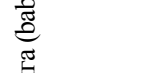 & 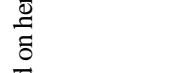 & & & $\begin{array}{l}\text { grandma Yaga. She's flying with broom among } \\
\text { people, ahaa! }\end{array}$ & + & \\
\hline 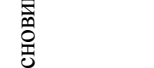 & 莺 & & & $\begin{array}{l}\text { Herridan, who, by her broom, is plodding through the } \\
\text { lovely men }\end{array}$ & & + \\
\hline 鼠无 & $\sum_{i}^{\infty}$ & & 节 & $\begin{array}{l}\text { Baba Yaga-witch, who between kind people on her } \\
\text { broom dreams }\end{array}$ & + & \\
\hline 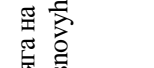 & 葛 & & : & $\begin{array}{l}\text { a grandma-hag. Among good people on the broom } \\
\text { roams gad }\end{array}$ & & + \\
\hline 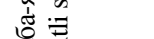 & 窇 & & $\cdot \stackrel{1}{\Xi}$ & Baba Yaha, who on broom among people passing by & + & \\
\hline 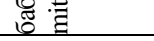 & है & & $\bar{D}$ & You see how Baba Yaga's broom skirrs & + & \\
\hline & & tender and innocent & & one girlie, like Goosewhite & + & \\
\hline 蛋 & & image of a little girl who & & one cutie, one little girl & & + \\
\hline 氕 & 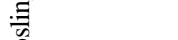 & is compared to white & & girl, as tender as swan & & + \\
\hline$\underline{0} \div$ & $\stackrel{0}{\circ}$ & gosling because white & & a white goosy girl & + & \\
\hline 诸 辛 & $\stackrel{\mathscr{I}}{=}$ & color is a symbol of & 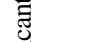 & lonely girl as white as snow & & + \\
\hline 厸 & $\overline{3}$ & purity in Ukraine. & $\stackrel{G}{\rightrightarrows}$ & one little, like a white goose, girl & + & \\
\hline 号 芫 & $\ddot{\mathscr{g}}$ & & $\frac{500}{60}$ & one little wonderful girl & & + \\
\hline$\sqrt{5}$ & 前 & & $\cdot \frac{1}{\Xi}$ & one little girl, like a white gosling & + & \\
\hline & $\overline{B_{0}}$ & & $\bar{D}$ & one little girl, who like white fluffy gooselet & + & \\
\hline
\end{tabular}


Table 4. English native speakers' feedbacks on students' experimental variations on the given Ukrainian ethnotext

\begin{tabular}{|c|c|c|c|c|c|c|c|}
\hline 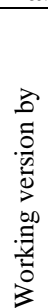 & & 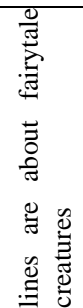 & 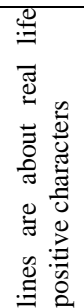 & 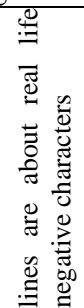 & 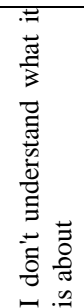 & 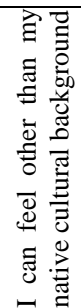 & 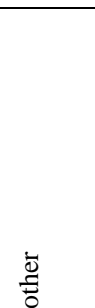 \\
\hline 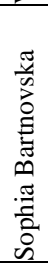 & $\begin{array}{l}\text { This stick gonna show you some magic today } \\
\text { Look, frog is not normal, it‘s Queen, so you sway! } \\
\text { Here‘s kitty-too-sweety, and grandma Yaga } \\
\text { She‘s flying with broom among people, ahaa!! } \\
\text { But suddenly girl, as tender as swan } \\
\text { Said „Lovely granny!“and right after than } \\
\text { Yaga stomped her foot, how dare this face-branny } \\
\text { Call evil-grandma, so simply as granny! }\end{array}$ & $80 \%$ & & & $20 \%$ & & \\
\hline 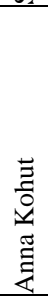 & $\begin{array}{l}\text { Tonight this wand will be magical } \\
\text { The frog here isn't simple - it's a fantastical animal } \\
\text { Look! There is a kitty cat and also a woman } \\
\text { She flies her broom all around the world being so inhu- } \\
\text { man } \\
\text { This woman's name is terrible and scary } \\
\text { But one cutie, one little girl once called her 'Granny' } \\
\text { She got mad, dispersed the clouds } \\
\text { 'Call me by my name, I don't like other sounds!' }\end{array}$ & $\begin{array}{l}100 \\
\%\end{array}$ & & & & & $\begin{array}{l}\text { sounds } \\
\text { like a } \\
\text { rhyme }\end{array}$ \\
\hline 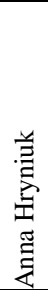 & $\begin{array}{l}\text { Today this stick is magic wand. } \\
\text { And just a frog is Princess-toad. } \\
\text { Look, there is a furry cat } \\
\text { And there is Herridan, who, by her broom, } \\
\text { is plodding through the lovely men. } \\
\text { But lonely girl as white as snow, } \\
\text { Once said her: You're an old-one! } \\
\text { So witch gone mad and stomp her leg } \\
\text { To make the girl politely chat! }\end{array}$ & $\begin{array}{l}100 \\
\%\end{array}$ & & & & & \\
\hline 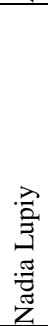 & $\begin{array}{l}\text { Today this wand'll become magical } \\
\text { It's the Frog Princess, not just usual. } \\
\text { Here's a kitty, purring sweetly. } \\
\text { Here's Baba Yaha, who on broom among people passes } \\
\text { by. } \\
\text { «It's Granny Yahusia!» } \\
\text { It was suddenly said } \\
\text { By one little girl, who like white fluffy gooselet. } \\
\text { But Baba just trampled her with spite, } \\
\text { So she calls her Yaga, not otherwise. }\end{array}$ & $90 \%$ & & & & $10 \%$ & \\
\hline 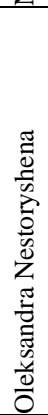 & $\begin{array}{l}\text { Now the stick is becoming a wand } \\
\text { And you'll spread the magic all over you stand. } \\
\text { The frog is now a fabulous princess! } \\
\text { And a common cat is purring like kitten. } \\
\text { The horrible witch called Baba Yaga } \\
\text { Is flying around and scream 'Ahaha!' } \\
\text { A nice little girl was taking a stroll } \\
\text { Suddenly witch flew fast like a ball } \\
\text { The old woman landed just near the child } \\
\text { "Good morning, nice granny!" girl said and then smiled. } \\
\text { The horrible witch has quickly got mad: } \\
\text { "How dare you greet me something like that!" }\end{array}$ & $90 \%$ & & & & $10 \%$ & \\
\hline
\end{tabular}

Conclusions. The analyzed subject matter focuses on the field of linguistic research that deals with interrelations between language, thinking, way of life, and the reality. Ethnolinguistic competence is derived from Ethnolinguistics which deals with the human language - especially its vocabulary - as a source of knowledge about humanity and the surrounding (often historically bound). Ethnolinguistic competence helps students to identify lexical connotations established in the transitive sense of a word; recognize ethno specific elements of a given language; point out and explain the relation between the inner form of a word and the culture and mentality it occurs in. In other words, ethnolinguistic competence for translators presupposes recognition of: the complex nature of human languages, especially English and Ukrainian; the contemporary trends in the usage of Ethnolinguistic research in translation practice; the relation between the inner form of a word and English (British and American) and Ukrainian culture and mentality. Ethnolinguistic competence, nevertheless, is not the one to be drilled of imposed, it can be evoked, induced and gradually developed. 


\section{REFERENCES}

1. Alves, F. (2007) Modelling translator's competence: Relevance and expertise under scrutiny. In Doubts and Directions in Translation Studies. - Amsterdam: Philadelphia: Benjamins, P. $41-55$.

2. Appel, R., Muysken, P. (2005) Language Contact and Bilingualism, Amsterdam University Press, 228 p.

3. Bartmiński, J. (2012) Aspects of Cognitive Ethnolinguistics. Sheffield and Oakville, CT: Equinox, 2009/2012.3.

4. Bell R. (2001) Psycholinguistic/cognitive approaches to translation. In Routledge Encyclopedia of Translation Studies. London: Routledge, P. 185 - 190.

5. Bourdieu, P.(1993) The Field of Cultural Production, Cambridge, Polity Press, 322 p.

6. Chesterman, A.(1998) Causes, Translations, Effects, Target, Manchester, pp. 205-208.

7. Corbin, R. (1980) Decisions that Might not be Made. Ed. by T. Wallsten. Cognitive Processes in Choice and Decision Behaviour. - Hillsdale: Erlbaum, P. 47 - 67.

8. Cummins, J. (2007) International Handbook of English Language Teaching, Springer Science \& Business Media, $1262 \mathrm{p}$.

9. Danks, J. (1996) Cognitive Processes in Translation and Interpreting. - London: New Dehli: Sage Publications, 214 p.

10. House, J. (1977). A Model for Translation Quality Assessment. Tübringen: Narr.

11. Kostenko, L. (1987) Buzy`novy`j czar. Virshi. Ky`yiv. "Veselka". Костенко Ліна. Бузиновиц цар. Вірші. - Київ : Веселка.
12. Plas, P. 2006. Slavic ethnolinguistics and Anglo-American linguistic anthropology: Convergences and divergences in the study of the language-culture nexus. Etnolingwistyka 18: 135-143.

13. Sharifian, F. (2011) Cultural Conceptualisations and Language: Theoretical Framework and Applications. Amsterdam/Philadelphia: John Benjamins.

14. Sharifian, F., Palmer, G. (2007) Applied cultural linguistics: Implications for second language learning and intercultural communication. Amsterdam/Philadelphia: John Benjamins.

15. Stockwell, P. (2002) Sociolinguistics: A Resource Book for Students, London, Routlage.

16. Tabakowska, E. (2013). A linguistic picture, image, or view of "Polish CognitiveStudies". In: Adam

Głaz, David S. Danaher and Przemysław Łozowski (eds.) The Linguistic Worldview. Ethnolinguistics, Cognition and Culture. 321-338.London: Versita.

17. Tuan, Y. (1974) Topophilia: A study of environmental perception, attitudes, and values. Englewood Cliffs, N.J.: Prentice Hall.

18. Underhill J. (2012) Ethnolinguistics and cultural concepts: Truth, Love, Hate and War, Cambridge University Press, 248 p.

19. Wierzbicka, A. (1992) Semantics, Culture, and Cognition: Universal human concepts in culture-specific configuration. New York: Oxford University Press. 